\title{
Review \\ Effects of SARS-CoV-2 on Cardiovascular System: The Dual Role of Angiotensin-Converting Enzyme 2 (ACE2) as the Virus Receptor and Homeostasis Regulator-Review
}

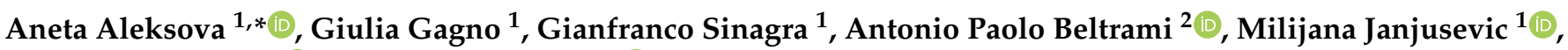
Giuseppe Ippolito $^{3}{ }^{-}$, Alimuddin Zumla ${ }^{4,5}$, Alessandra Lucia Fluca ${ }^{1, \dagger}$ and Federico Ferro ${ }^{1, \dagger}$

1 Cardiothoracovascular Department, Azienda Sanitaria Universitaria Giuliano Isontina (ASUGI) and Department of Medical Surgical and Health Science, University of Trieste, 34149 Trieste, Italy; gagnogiulia@gmail.com (G.G.); gianfranco.sinagra@asugi.sanita.fvg.it (G.S.); mjanjusevic@units.it (M.J.); alessandralucia.fluca@units.it (A.L.F.); fferro@units.it (F.F.)

2 Department of Medicine (DAME), University of Udine, 33100 Udine, Italy; antonio.beltrami@uniud.it

3 National Institute for Infectious Diseases Lazzaro Spallanzani-IRCCS, 00135 Rome, Italy; giuseppe.ippolito@inmi.it

4 Department of Infection, Division of Infection and Immunity, Centre for Clinical Microbiology, University College London, London NW3 2PF, UK; a.zumla@ucl.ac.uk

5 National Institute for Health Research Biomedical Research Centre, University College London Hospitals, London NW1 2BU, UK

Citation: Aleksova, A.; Gagno, G.; Sinagra, G.; Beltrami, A.P.; Janjusevic, M.; Ippolito, G.; Zumla, A.; Fluca,

A.L.; Ferro, F. Effects of SARS-CoV-2 on Cardiovascular System: The Dual Role of Angiotensin-Converting Enzyme 2 (ACE2) as the Virus Receptor and Homeostasis Regulator-Review. Int. J. Mol. Sci. 2021, 22, 4526. https://doi.org/ $10.3390 /$ ijms 22094526

Academic Editor: Francesco Caruso

Received: 7 April 2021

Accepted: 25 April 2021

Published: 26 April 2021

Publisher's Note: MDPI stays neutral with regard to jurisdictional claims in published maps and institutional affiliations.

Copyright: (C) 2021 by the authors. Licensee MDPI, Basel, Switzerland. This article is an open access article distributed under the terms and conditions of the Creative Commons Attribution (CC BY) license (https:/ / creativecommons.org/licenses/by/ $4.0 /)$.
* Correspondence: aaleksova@units.it or aaleksova@gmail.com; Tel.: +39-340-550-7762; Fax: +39-040-399-4878

+ These authors contributed equally to this work.

Abstract: Angiotensin-converting enzyme 2 (ACE2) is the entry receptor for severe acute respiratory syndrome coronavirus-2 (SARS-CoV-2), the cause of Coronavirus Disease-2019 (COVID-19) in humans. ACE-2 is a type I transmembrane metallocarboxypeptidase expressed in vascular endothelial cells, alveolar type 2 lung epithelial cells, renal tubular epithelium, Leydig cells in testes and gastrointestinal tract. ACE2 mediates the interaction between host cells and SARS-CoV-2 spike (S) protein. However, ACE2 is not only a SARS-CoV-2 receptor, but it has also an important homeostatic function regulating renin-angiotensin system (RAS), which is pivotal for both the cardiovascular and immune systems. Therefore, ACE2 is the key link between SARS-CoV-2 infection, cardiovascular diseases (CVDs) and immune response. Susceptibility to SARS-CoV-2 seems to be tightly associated with ACE2 availability, which in turn is determined by genetics, age, gender and comorbidities. Severe COVID-19 is due to an uncontrolled and excessive immune response, which leads to acute respiratory distress syndrome (ARDS) and multi-organ failure. In spite of a lower ACE2 expression on cells surface, patients with CVDs have a higher COVID-19 mortality rate, which is likely driven by the imbalance between ADAM metallopeptidase domain 17 (ADAM17) protein (which is required for cleavage of ACE-2 ectodomain resulting in increased ACE2 shedding), and TMPRSS2 (which is required for spike glycoprotein priming). To date, ACE inhibitors and Angiotensin II Receptor Blockers (ARBs) treatment interruption in patients with chronic comorbidities appears unjustified. The rollout of COVID-19 vaccines provides opportunities to study the effects of different COVID-19 vaccines on ACE2 in patients on treatment with ACEi/ARB.

Keywords: cardiovascular system; ACE2; RAS; COVID-19; SARS- CoV-2; TMPRSS2; ADAM17; pandemic; vaccines

\section{Introduction}

Severe acute respiratory syndrome coronavirus 2 (SARS-CoV-2) was first identified as a novel human pathogen in December 2019 and since has caused a worldwide pandemic [1] As of 8 February 2021, there have been over 105 million Coronavirus Disease-2019 (COVID19) cases including 2.3 million deaths reported by the World Health Organization (WHO) [2]. 
Epidemiologic studies highlight that age, gender and comorbidities (hypertension, renal insufficiency, diabetes and ischemic heart disease) are frequently associated with greater mortality risk after SARS-CoV-2 infection $[3,4]$.

The pathogenesis of COVID-19 has two stages [5-7]: the first one, where SARS-CoV-2 replicates and patients manifest a range of non-specific symptoms (e.g., fever, muscle aches, shortness of breath, headache, sore throat and gastrointestinal discomfort) $[3,6]$. The second stage is characterized by an adaptive immune response with humoral, cellular and cytokine responses manifesting in a large range of clinical presentations [6]. Some patients develop the most severe forms of COVID-19, leading to fatal complications such are acute respiratory distress syndrome (ARDS), acute kidney injury and thromboembolism [3,6].

Angiotensin-converting enzyme 2 (ACE2) is the entry receptor for SARS-CoV-2, which is the cause of COVID-19 in humans. ACE2 is a type I transmembrane metallocarboxypeptidase expressed in endothelial cells, alveolar type 2 lung epithelial cells, renal tubular epithelium, Leydig cells in the testes, and gastrointestinal tract [7]. ACE2 mediates the interaction between host cells and SARS-CoV-2 spike (S) protein [8]. However, ACE2 is not only a SARS-CoV-2 receptor. Indeed, it also has an important homeostatic function regulating renin-angiotensin system (RAS), which is pivotal for both the cardiovascular and immune systems [9]. Therefore, ACE2 appears to be the key link between SARS-CoV-2 infection, cardiovascular diseases (CVDs) and immune response $[8,10,11]$. RAS pathway has a fundamental role in human body homeostasis and its imbalance is associated with inflammation and cardiovascular alterations $[12,13]$. SARS-CoV-2 binds to human cells through ACE2, and it appears that pre-existing alterations in ACE2 expression and activity could determine susceptibility to SARS-CoV-2 infections [4,14].

The aim of this review is to summarize the state of the art in ACE2-SARS-CoV-2 interactions in the context of the cardiovascular system and to discuss the implications and impact of the use of ACE inhibitors (ACEi) and angiotensin receptor blockers (ARB) in patients with SARS-CoV-2 infection. We also discuss the rollout of COVID-19 vaccines and the opportunities this provides to study the effects of different COVID-19 vaccines on ACE2 in patients on treatment with ACEi/ARB.

\section{ACE2 Physiological Role}

The ACE2 gene, located on chromosome Xp22, consists of 18 exons and 20 introns [15] and encodes a type I transmembrane glycoprotein of 805 amino acids [16,17]. The Nterminal catalytically active domain is located in the extracellular space while the intracellular C-terminal consists of a collectin and an insulin-like domain [16,17].

In RAS, Renin produces Angiotensin I (Ang I) starting from Angiotensinogen, then angiotensin-converting enzyme (ACE) removes two amino acids from Ang I generating the active peptide Angiotensin II (Ang II) [18]. In the classical RAS, Ang II binds to angiotensin type 1 and 2 receptors (AT1R e AT2R) promoting vasoconstriction, inflammation, increase of blood pressure and myocardial contraction [18]. ACE2 acts in a different way: specifically, it generates Angiotensin 1-7 (Ang 1-7) after Ang II cleavage [18,19]. Subsequently, Ang 1-7 is responsible for vasodilatation and for the production of anti-inflammatory molecules by interacting with Mas receptor (MasR) [18]. Furthermore, ACE2 acts on Ang I, forming Angiotensin 1-9 (Ang 1-9), thus contributing to the reduction of Ang I availability for classical RAS [13].

ACE2 undergoes proteolytic cleavage at different sites by both the type II transmembrane serine protease (TMPRSS2) and ADAM Metallopeptidase Domain 17 (ADAM17) [20-22]. Specifically, ADAM17 activity on ACE2 generates an extracellular soluble ACE2 (sACE2) fragment (i.e., shedding) [20]. A recent study demonstrated that, after shedding, the remaining transmembrane fragment is targeted by $\gamma$-Secretase generating an intracellular domain (ICD) [23]. Preliminary analyses suggest that ICD is not involved in the regulation of ACE2, TMPRSS2 or ADAM17 expression [23]. The ADAM17-mediated shedding is a constitutive mechanism that is suppressed by TMPRSS2 activity $[24,25]$. 


\section{ACE2 Balance and SARS-COV-2 Infection}

SARS-CoV-2 interacts with host cells through the surface spike (S) protein [26]. Initially, $\mathrm{S}$ protein undergoes activation after proteolytic cleavage by furin and TMPRSS2 (i.e., priming) on the cell surface [26]. This cleavage allows the separation between S1 and S2 subunits of $S$ protein [27]. As a result, the S2 subunit rearranges permitting the interaction with ACE2 and the subsequent endocytosis of viral particles [26,28]. Evidence of ACE2 cleavage by both TMPRSS2 and ADAM17, in physiological conditions and in SARS-CoV-2 infection, provides new insights for greater complexity in virus-host interaction [24]. Specifically, ACE2-S protein interaction increases ADAM17 activity [16]. The increase of ACE2 shedding reduces its availability on the cell surface and it also leads to the accumulation of Ang II, which in turn generates positive feedback for ACE2 shedding by enhancing ADAM17 activity $[14,20]$. At first sight, the reduced availability of ACE2, due to ADAM17 shedding, could be evaluated as a protective mechanism against SARS-CoV-2. However, ADAM17 activity could not be considered fully beneficial to counteract SARS-CoV-2 infection. In fact, it is still questionable whether SARS-CoV-2 trapping by sACE2 could promote the clearance of viral particles and prevent them from being internalized $[27,28]$. Nonetheless, it is likely that the protective effect of SACE2 is neutralized in case of high viral load. Furthermore, evidence suggests that ACE2 shedding could facilitate viral entry [16]. After viral infection, the innate immune system drives initial response via pattern recognition receptors (PRRs), as RIG-like receptors (RLRs) and Toll-like receptors (TLRs), mediating inflammation [29]. It has been documented that TLRs could activate ADAM17 leading to tumor necrosis factor alpha (TNF- $\alpha$ ), interleukin-6 (IL-6) and epidermal growth factor receptor (EGFR) after viral infection [14,30]. Furthermore, because the role of ACE2 is not limited to being a viral receptor [18], the Ang II accumulation causes the massive release of cytokines via AT1R [16]. Therefore, the "cytokine storm" triggers an uncontrolled immune response and tissue damage [16,29] (Figure 1).

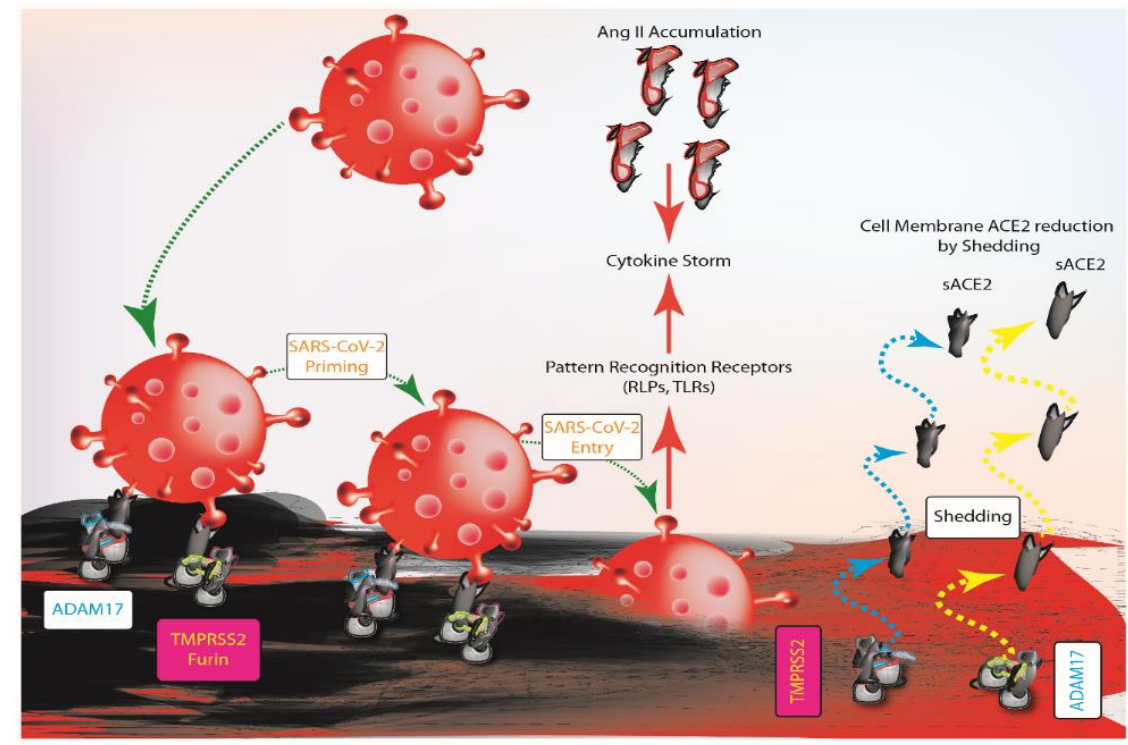

Figure 1. Schematic representation of host cell-SARS-CoV-2 interaction during infection before the interaction between virus and host cell, furin and TMPRSS2 cut the spike (S) protein. The process allows the interaction between $S$ protein and ACE2, which triggers the innate immune response. Ang II contributes to the inflammation sustaining the production of cytokines. ADAM17 and TMPRSS2 mediate the shedding process producing the soluble form of ACE2 thus influencing ACE2 availability on the cell surface and the interaction with SARS-CoV-2. ADAM17, ADAM metallopeptidase domain 17; TMPRSS2, type II transmembrane serine protease; sACE2, soluble ACE2; Ang II, angiotensin II; RLRs, RIG-like receptors; TLRs, toll-like receptors. 


\section{Does ACE2 Influence Probability of SARS-COV-2 Infection and Worse Outcome?}

There is great interest in factors that affect immune responses and increase susceptibility toward SARS-CoV-2 infection because they could be of great help in predicting patient outcomes. As described for other viral infections, part of the inter-individual susceptibility is determined by genetic variants [31]. "The COVID Human Genetic Effort" consortium has been formed to identify monogenic variants for resistance or susceptibility to SARS-CoV-2 [31] and study the differences of allele frequency among ethnic groups to explain the different susceptibility among various populations [31,32]. Analysis of ACE2, TMPRSS2 and ADAM17 genes is of particular interest because variants may influence the probability of cell-virus interaction and host response against SARS-CoV-2 infection [33]. In particular, the ACE2 gene exhibits high variability and up to date, more than 1700 variants have been described [15]. Some single nucleotide polymorphisms (SNPs) could influence ACE2 gene expression, activity and interaction with the $S$ protein thus affecting its binding affinity to SARS-CoV-2 [15,33-36]. Furthermore, several TMPRSS2 and ADAM17 polymorphisms have been identified and it has been demonstrated that some of these variants have higher expression and activity, thus influencing susceptibility toward SARS-CoV-2 infection $[15,34,35]$. Therefore, the association of polymorphisms with COVID-19 severity needs further investigation [15,35].

Along with genetic factors, habits such as cigarette smoking and diet seem to have a significant effect on ACE2. Nicotine appears to promote classical RAS accounting for cardiovascular complications and reduction of immune response efficiency $[37,38]$, and the expression of nicotinic acetylcholine receptors in airway cells may promote SARS-CoV-2 uptake through nicotine-mediated cellular signaling [39]. Consequently, smoking may influence susceptibility and therefore explain why many individuals with severe COVID-19 are also smokers [37,40-42]. In addition, salt- and glucose-rich diets may also influence ACE2 expression and activity, increasing the risk of RAS imbalance and SARS-CoV-2 susceptibility [14].

Studies are required to determine how age, gender and comorbidities influence ACE2 levels on the cell surface $[4,14]$. ACE2 expression is known to decrease with age and its reduction is stronger in males than females $[43,44]$. Because the ACE2 locus on the $\mathrm{X}$-chromosome is only partially inactivated, in theory, females have double the dose of the ACE2 gene with respect to males [45]. The discrepancy in ACE2 expression between genders could be also explained by hormonal factors [46,47]. Specifically, the decline of sex hormones with age could contribute to reduced ACE2 expression thus influencing SARS-CoV-2 susceptibility [43,46,47]. Furthermore, ACE2 shedding shows differences according to age and gender [48]. In line with this, preliminary observations propose that TMPRSS2 and ADAM17 transcription is also affected by sex hormones $[15,22]$. These data suggest that the association between age, gender and shedding needs further investigations. Furthermore, gender differences in susceptibility towards SARS-CoV-2 might be related to the immune response. In fact, many immune-associated genes (e.g., TLRs, RLRs) have an X-linked expression pattern, which is activated by hormones [45]. Specifically, estrogens have immuno-stimulant effects, while androgens are immunosuppressive [45]. Taken together, it is likely that the increase in ACE2 expression, reduced ACE2 cleavage and the more efficient immune response could contribute to lower SARS-CoV-2 susceptibility in females (Figure 2). 


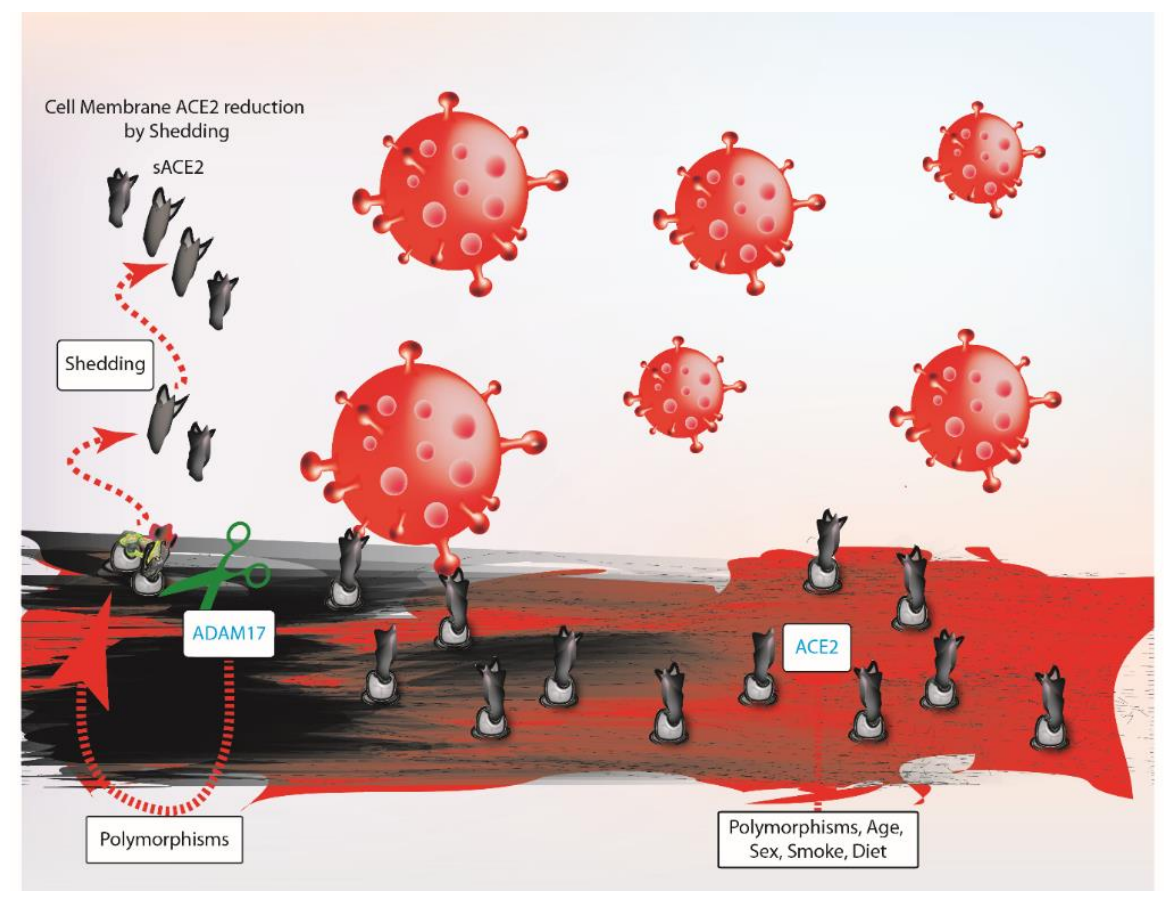

Figure 2. Schematic representation of ADAM17 activity, which efficiency depends on its polymorphisms. Differences between individuals for ACE2 are influenced by genetics factors coupled with habits such as smoking and diet. Therefore, the reduction of ACE2 availability on cell surface could explain variations in susceptibility among populations. ADAM17, ADAM metallopeptidase domain 17; ACE2, angiotensin-converting enzyme 2; sACE2, soluble ACE2.

Notably, although ACE2 has positive effects, its expression in human tissues exacerbates pathologies such as myocardial infarction, hypertension, diabetes mellitus and heart failure $[49,50]$. The reason for this discrepancy could be explained by the enhanced ADAM17 expression and activity in pathologic conditions, which corresponds to the increase of sACE2 concentration in plasma samples [30,51]. sACE2 concentration increases in patient cohorts with heart failure, mostly in males, and in patients with worse New York Heart Association functional class (NYHA) [18,51-53]. In patients with CVDs, the relation between the reduction of ACE2 protein on membranes and the susceptibility toward SARSCoV-2 is still unclear. These patients could manifest a higher risk of adverse outcomes after SARS-CoV-2 infection because the virus uptake could worsen the pre-existing RAS disequilibrium [54]. Furthermore, patients with diabetes could have a higher susceptibility to SARS-CoV-2 infection because diabetes is frequently associated with an altered immune system [37]. Specifically, diabetic patients have delayed immune response and maladaptive inflammatory response as a consequence of the infection of $\beta$-cells by SARS-CoV- 2 may aggravate clinical conditions [3,37] (Figure 3). 


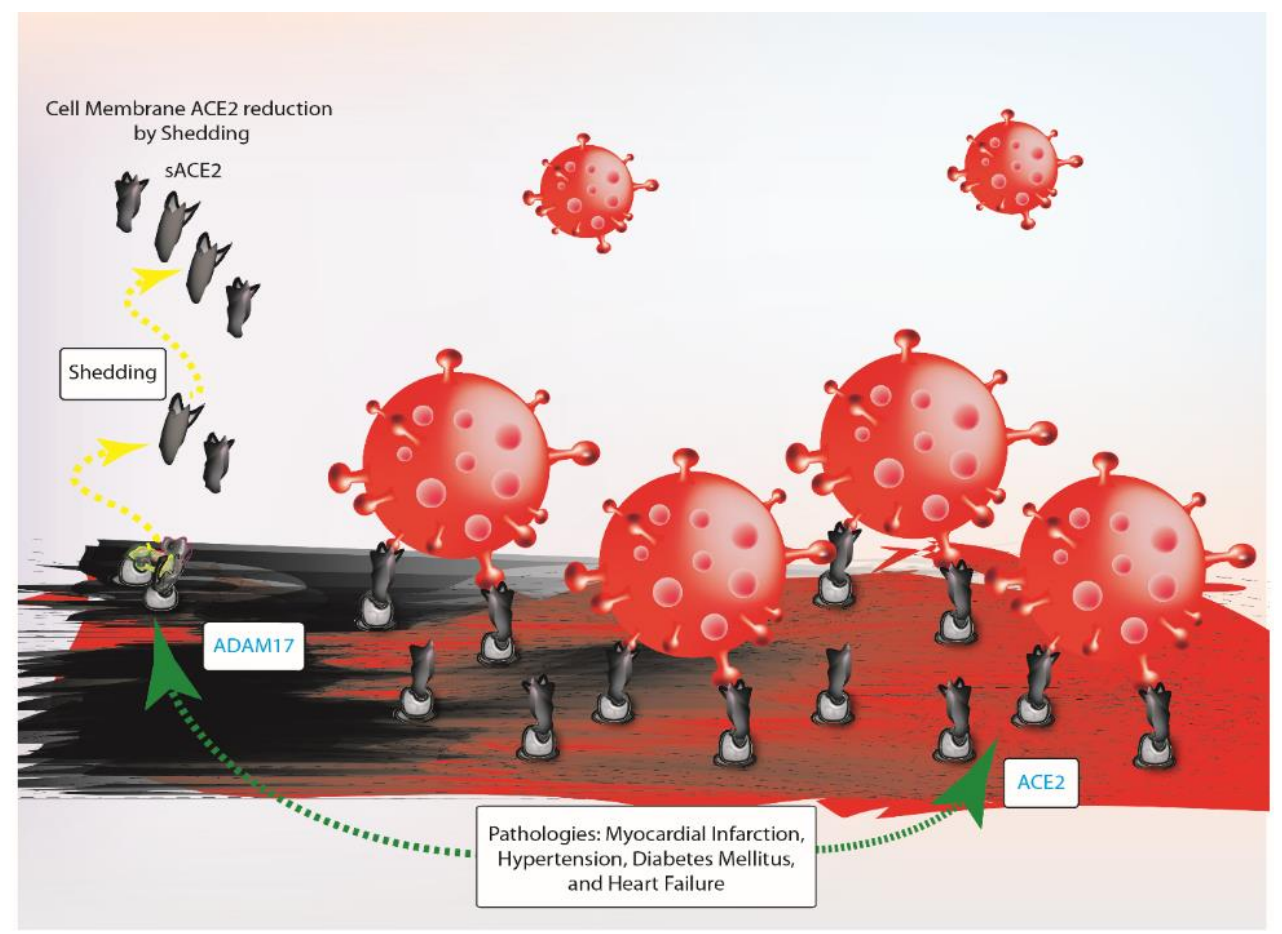

Figure 3. Pathologies such as myocardial infarction, hypertension, diabetes mellitus and heart failure increase the availability of ACE2 suggesting that comorbidities cause high susceptibility towards SARS-CoV-2. ADAM17, ADAM metallopeptidase domain 17; ACE2, angiotensin-converting enzyme 2; sACE2, soluble ACE2.

\section{SARS-COV-2 Infection Starts from Lungs and Involves Heart}

Airway epithelial cells are the first target of SARS-CoV-2 infection [29]. Severe cases of COVID-19 are frequently associated with multi-organ failure due to direct SARS-CoV2 cytotoxicity and massive cytokines release [29,55-57]. It is suggested that classifying ACE2 organ distribution could be useful to understand SARS-CoV-2 pathogenesis [9]. ACE2 expression was detected in various organs such as the heart, lung, kidneys, oral cavity, brain, pancreas, gastrointestinal tract and brain [7]. Therefore, it is likely that organ vulnerability and severity of pathology depend on the level of ACE2 gene expression $[7,9,58]$, aligning with the hypothesis that high ACE2 levels have been detected in both lungs and heart $[9,16,59]$. In addition, alveolar epithelial type II cells and cardiomyocytes (mostly aged ones) have high expression of genes that positively regulate viral reproduction and transmission thus, consistently with lung and heart vulnerability [22,60]. In contrast, the ileum is not the most vulnerable organ although it has the highest ACE2 expression [9]. This discrepancy requires further study. Additionally, alternative mechanisms of infection and organ susceptibility have been proposed such as ACE2 homodimers, co-receptor, and alternative receptors [9]. In ACE2 knockout mice, SARS-CoV-2 infection decreases but it is not completely prevented thus alternative host-virus interactions such as virus uptake in endosomes via cathepsin $\mathrm{L}$ need to be defined $[9,26,61,62]$. It is likely that multiple entry mechanisms might coexist, depending on target cell expression and pathological stages [9].

In severe COVID-19, it seems that early death occurs because of simultaneous respiratory failure and cardiac injury $[36,55]$. Autopsies on patients affected by COVID-19 with and without comorbidities clarified microscopic and macroscopic alterations in various organs after SARS-CoV-2 infection [63]. SARS-CoV-2 enhances classical RAS and may lead to multi-organ involvement and higher mortality. Interestingly, even patients without comorbidities manifest heart impairment [63] since patients admitted to intensive care units (ICU) have significantly increased levels of myocardial injury markers (i.e., creatine kinase-MB, high-sensitivity cardiac Troponin I) [7]. To date, the exact molecular mechanisms that correlate with myocardial injury following SARS-CoV-2 infection remain to 
be defined [64]. Current data indicate that cardiovascular injury in COVID-19 is probably of multifactorial origin. Specifically, ARDS and reduced pulmonary functionality are due to an excessive and uncontrolled immune response, which has destructive effects on vasculature and alveoli $[7,65]$. Consequently, ARDS leads to low oxygen saturation levels and low oxygen supply to organs causing hypoxia and oxidative stress, which alter their normal functionality. Severe hypoxia increases the probability of cardiovascular injury and mortality risk [6]. SARS-CoV-2 infection leads to systemic inflammation causing an increase in blood viscosity, endothelial dysfunction, activation of the coagulation cascade and atherosclerotic plaque rupture [57]. Autopsies of individuals with COVID-19 have shown the presence of macrophages infiltration in damaged tissues [66]. It is likely that the increased systemic levels of pro-inflammatory cytokines could explain the elevated macrophage infiltration [67]. However, it may be that myocardial injury is associated with other mechanisms than macrophages infiltration [67]. Myocyte necrosis could be due to lymphocytes infiltration $[66,68]$ and direct SARS-CoV-2 cytotoxicity after cardiomyocyte infection occurring in cases of high viral load and longer exposure time [64]. Thus, SARSCoV-2-associated myocardial damage could be due to increased cytokines, cell-mediated immune response and direct cardiomyocytes infection $[64,67,69]$. All these factors increase the probability of the formation of micro-thrombi and myocardial infarction.

Apart from immune response and direct cytotoxicity, the effects of SARS-CoV-2 on the heart may arise from RAS disequilibrium. Severe cardiovascular complications are frequently associated with Ang II accumulation because of ACE2 decrease [13]. In particular, Ang II induces the increase of cardiomyocyte contractility and converts cardiac fibroblasts to pro-fibrotic myofibroblasts, which enhance the production of RAS signaling component and TGF- $\beta$ [12]. Additionally, Ang II exerts effects on endothelial cells, which secrete cytokines, and on inflammatory cells leading to their activation [12]. As a result, the previously described effects of Ang II combined with Ang II-mediated oxidative stress promote cardiac remodeling, leading to hypertrophy. Therefore, ACE2-virus internalization and ACE2 shedding in SARS-CoV-2 infection suggests that these alterations could exacerbate cardiovascular damage [7].

\section{Is ACEI/ARB Therapy during SARS-COV-2 Infection Safe?}

According to guidelines, ACEi/ARB therapy reduces mortality rates in patients with acute myocardial infarction, heart failure, hypertension and diabetes [70,71]. ACEi/ARB blocks the ACE/Ang II/AT1R axis thus limiting Ang II production and enhance ACE2 expression thus potentiating its positive effects [70,71]. Because of increased ACE2 expression in patients with chronic treatment with $\mathrm{ACEi} / \mathrm{ARB}$, it is suggested that these patients might have a higher risk of SARS-CoV-2 infection and severe COVID-19 [72]. On the other hand, therapy suspension may worsen chronic illness and reduce survival probability after SARS-CoV-2 infection. Considering SARS-CoV-2 perturbations on RAS equilibrium, there is a great interest in evaluating the necessity of ACEi/ARB therapy suspension or compliance in the context of SARS-CoV-2 infection. Numerous studies suggest that ACEi/ARB therapy does not influence negatively mortality or susceptibility to virus infection [73-77]. Furthermore, evidence of ACEi/ARB effectiveness is reported in publications based on meta-analysis as well $[78,79]$. The recent BRACE-CORONA trial suggests that treatment interruption does not positively affect the survival of COVID-19 patients, thus ACEi/ARB therapy should be continued [80]. On the contrary, a small number of studies do not recommend the use of ACEi/ARB. However, these studies suffer from limited cohort numbers that confound the interpretation and significance of the analysis [81,82]. Therefore, current guidelines of international and Italian scientific cardiovascular societies recommend not to interrupt ACEi/ARB treatment in patients with chronic comorbidities, even temporarily.

\section{Do COVID-19 Vaccines Influence ACE2 Availability?}

As of 7 April 2021, according to the WHO, there are 86 COVID-19 vaccines in clinical development and 186 under pre-clinical evaluation [83]. The Pfizer-BioNTech (BNT162b2), 
Moderna (mRNA-1273) and AstraZeneca ChAdOx1 nCoV-19 (AZD1222) vaccines are being rolled out currently $[84,85]$. All three vaccines promote humoral and cellular immune responses against $\mathrm{S}$ protein of SARS-CoV-2 [86,87]. At the present time, European Medicine Agency (EMA) is evaluating additional three COVID-19 vaccines: Russia's Gamaleya National Centre of Epidemiology and Microbiology (Sputnik V), CureVac AG (CVnCoV) and Novavax CZ AS (NVX-CoV2373) [88].

In BNT162b2 and mRNA-1273, lipid nanoparticles (LNPs) carry nucleoside-modified RNA coding full-length $S$ proteins with two proline mutations to keep it in the pre-fusion conformation $[86,87,89]$. Specifically, BNT162b2 administration consists of two doses of $30 \mu \mathrm{g}$ within 21 days of each other, while two doses of $100 \mu \mathrm{g}$ at the same time distance are needed for mRNA-1273 [90,91]. Clinical studies guarantee $95 \%$ and $94.1 \%$ efficacy for BNT162b2 and mRNA-1273 respectively [90,91]. On the other hand, AZD1222 uses a replication-incompetent chimpanzee adenovirus vector as a delivery vehicle for the wild-type version of $S$ protein [92]. According to a pre-clinical trial on rhesus macaques, the main advantage of this strategy consists of inducing innate and adaptive immune response as in the case of viral infection [87]. The injection of $5 \times 10^{10}$ viral particles leads to $70 \%$ of efficacy once the second dose is administrated after about 21 days within the first dose [92]. Recent events of thromboembolisms after AZD1222 administration indicated the necessity of further investigations on its safety. However, the EMA final report indicates that the vaccine is not associated with an increased risk of blood clotting [93].

Furthermore, among the COVID-19 vaccines under clinical evaluation, the Italian biotechnological company ReiThera developed the GRAd-COV2 vaccine based on replicationincompetent gorilla adenoviral vector encoding the full-length $S$ protein [94]. This viral vector has advantages as low human exposure to gorilla adenovirus, high vector efficacy and possible strong immune response [94]. In light of the success of phase 1 trials approved by the Italian Medicine Agency (AIFA), the COVITAR trial is currently assessing phase two and three of clinical trials [94-96].

The aim of these strategies is to deliver nucleic acid, via LNPs or viral vector, which subsequently allows for $\mathrm{S}$ protein production in host cells. The presentation of peptides, from S protein, on class I and class II MHC, drives the humoral and cell-mediated immune response [97]. Studies confirm that vaccine administration leads to the production of neutralizing antibodies and robust CD8+ and CD4+ T-cell (Th1) response [90-92,98]. However, because BNT162b2 and mRNA-1273 are injected intramuscularly, it is likely that they do not induce strong mucosal immunity with the production of IgA to protect the upper respiratory tract [87]. Based on previous observations on SARS-CoV, S protein induces the reduction of ACE2 expression [99]. Notably, in a recent study, in vitro and in vivo analyses show that the $S$ protein of SARS-CoV-2 could cause an ACE2 decrease as well [100]. However, it is still unknown if SARS-CoV-2 $\mathrm{S}$ protein expression in host cells could affect ACE2 availability on the cell surface after vaccination thus further investigations are needed.

\section{Challenges}

The unprecedented global efforts in developing safe and effective vaccines and making them available after rapid approval is an encouraging starting point to contain the explosive global spread of SARS-CoV-2. Apart from a regular supply of vaccines, prioritizing vaccine rollout and cold chain administration issues, several challenges remain. These include the effects of vaccines in older patients and those with comorbidities, as well as the longterm immunity benefits and efficacy on new South Africa, UK and Brazil SARS-CoV-2 variants $[101,102]$. To date, vaccination priority lists vary among nations depending on various socio-economic factors [101].

The discovery of new variants and slow vaccination campaigns might raise the risk of immune escape [103]. New emerging evidence has confirmed the worldwide presence of three main SARS-Cov-2 variants, 501Y.V1 (B.1.1.7), 501Y.V2 (B.1.351) and 501Y.V3 (P.1) respectively identified in The United Kingdom, South Africa and Brazil, which show immune escape thus, raising doubts about their influence on the effectiveness of current 
vaccines and hyper-immune serum. Hyper-immune serum obtained from the plasma of patients who had COVID-19 or animals, thereby inoculated with SARS-CoV-2 antigens, has been also authorized to successfully treat COVID-19 patients showing benefits in asymptomatic or symptomatic patients within three days [104,105]. Interestingly, the 501Y.V2 (B.1.351) viral variant confers partial to complete resistance to hyper-immune serum and reduces the efficacy of the AZD1222 vaccine [92] and sera from Pfizer-BioNTech and Moderna subjects displayed considerably decreased effects on 501Y.V2 [106]. As a consequence, pharmaceutical companies, proposing that changing the immunization sequence would cause a comparable neutralizing effect, trying to counteract the viral variants by replacing the original SARS-CoV-2 immunizing sequence with the 501Y.V2 sequences (i.e., Moderna) [107]. Therefore, these variants might be especially challenging in patients with cardiovascular diseases based on recent observations on animals [108].

Based on experience on vaccine production against other Coronaviruses some key points need further consideration [86]. Namely, hypersensitivity reactions driven by the high Th2 type response with eosinophil infiltration and abnormal antibody responses triggering the potential systemic breakdown are of particular importance [86]. However, it is still unknown if SARS-CoV-2 vaccines could have the same effects. To date, all studies of SARS-CoV-2 vaccines guarantee previously reported efficacy on specific age groups (16-55 years old BNT162b2; 18-65 years old mRNA-1273; 18-55 years old AZD1222) [90-92]. Furthermore, trials evaluating BNT162b2, mRNA-1273 and AZD1222 on elder individuals suggest that they are as safe as younger groups with the same antibody and cell response [91,109,110].

\section{Conclusions}

The intimate crosstalk between SARS-CoV-2 and ACE2 is even more complex than solely virus-receptor interaction. In fact, many pre-existing comorbidities originate from RAS misbalance causing higher susceptibility to virus or an increase of mortality risk after infection. Of note, it seems that death happens more frequently in case of cardiovascular injury. In fact, after SARS-CoV-2 infection, the virus mediates the worsening of clinical conditions because of its cytotoxicity, uncontrolled inflammatory response and RAS homeostasis loss. In this particular scenario, therapeutic approaches need close evaluation to avoid even more harmful effects. Contextually, ACEi/ARB is suggested as safe pharmacological therapy. In light of the recent vaccination campaign, further studies regarding the side effects of vaccines on pharmaceutical therapies and on ACE2 expression and physiological presence are also necessary. To date, ACEi/ARB treatment interruption in patients with chronic comorbidities appears unjustified. The rollout of COVID-19 vaccines provides opportunities to study their side effects and specific protective effects on ACE2 also in patients on treatment with ACEi/ARB.

Author Contributions: Conceptualization, A.A.; writing—original draft preparation, A.L.F., F.F., G.G., G.S., A.P.B., M.J., G.I., A.Z.; writing—review and editing, A.L.F., F.F., G.G., G.S., A.P.B., M.J., G.I., A.Z.; images, F.F. All authors have read and agreed to the published version of the manuscript.

Funding: This research received no external funding.

Acknowledgments: Zumla and Ippolito, are co-PI's of the European and Developing Countries Clinical Trials Partnership the EU Horizon 2020 Framework Program, projects a) Pan-African Network on Emerging and Re-Emerging Infections (Available online: https:/ / www.pandora-id.net/ (accessed on April 2021)). Zumla is in receipt of a UK-National Institutes of Health Research Senior Investigator award and is a 2020 Mahathir Science Award Laureate. The National Institute for Infectious Diseases Lazzaro Spallanzani-IRCCS, Rome, Italy has been funded by the Italian Ministry of Health (Ricerca Corrente line 1, COVID-2020-12371735 and COVID-2020- 12371817).

Conflicts of Interest: The authors declare no conflict of interest. 


$\begin{array}{ll}\text { Abbreviations } \\ \text { ACE2 } & \text { Angiotensin-converting enzyme 2 } \\ \text { ACEi } & \text { Angiotensin-converting enzyme inhibitors } \\ \text { AIFA } & \text { Italian Medicine Agency } \\ \text { ARB } & \text { Angiotensin receptor blockers } \\ \text { ADAM17 } & \text { ADAM metalloproteinase domain 17 } \\ \text { Ang 1-7 } & \text { Angiotensin 1-7 } \\ \text { Ang 1-9 } & \text { Angiotensin 1-9 } \\ \text { Ang I } & \text { Angiotensin I } \\ \text { Ang II } & \text { Angiotensin II } \\ \text { ARDS } & \text { Acute respiratory distress syndrome } \\ \text { AT1R } & \text { Angiotensin type 1 receptor } \\ \text { AT2R } & \text { Angiotensin type 2 receptor } \\ \text { COVID-19 } & \text { Coronavirus disease 2019 } \\ \text { CVDs } & \text { Cardiovascular diseases } \\ \text { EGFR } & \text { Epidermal Growth Factor Receptor } \\ \text { EMA } & \text { European Medicine Agency } \\ \text { IL-6 } & \text { Interleukin-6ICD Intracellular domain } \\ \text { MasR } & \text { Mas receptor } \\ \text { NYHA } & \text { New York Heart Association functional class } \\ \text { RAS } & \text { Renin-angiotensin system } \\ \text { RLRs } & \text { RIG-like receptors } \\ \text { sACE2 } & \text { Soluble ACE2 fragment } \\ \text { SARS-CoV-2 } & \text { Severe acute respiratory syndrome coronavirus 2 } \\ \text { TLRs } & \text { Toll-like receptors } \\ \text { TMPRSS2 } & \text { Type II transmembrane serine protease } \\ \text { TNF- } \alpha & \text { Tumor necrosis factor alpha References } \\ & \end{array}$

\section{References}

1. Wang, C.; Horby, P.W.; Hayden, F.G.; Gao, G.F. A novel coronavirus outbreak of global health concern. Lancet 2020, $395,470-473$. [CrossRef]

2. Johns Hopkins University. Coronavirus COVID-19 Global Cases. Available online: https://coronavirus.jhu.edu/map.html (accessed on 11 February 2021).

3. Ashraf, O.; Virani, A.; Cheema, T. COVID-19: An Update on the Epidemiological, Clinical, Preventive, and Therapeutic Management of 2019 Novel Coronavirus Disease. Crit. Care Nurs. Q. 2021, 44, 128-137. [CrossRef]

4. Istituto Superiore di Sanità. Caratteristiche dei Pazienti Deceduti Positivi all'Infezione da SARS-CoV-2 in Italia. Available online: https:/ / www.epicentro.iss.it/coronavirus/sars-cov-2-decessi-italia (accessed on 11 February 2021).

5. Sungnak, W.; Huang, N.; Becavin, C.; Berg, M.; Queen, R.; Litvinukova, M.; Talavera-Lopez, C.; Maatz, H.; Reichart, D.; Sampaziotis, F.; et al. SARS-CoV-2 entry factors are highly expressed in nasal epithelial cells together with innate immune genes. Nat. Med. 2020, 26, 681-687. [CrossRef]

6. Tan, W.; Aboulhosn, J. The cardiovascular burden of coronavirus disease 2019 (COVID-19) with a focus on congenital heart disease. Int. J. Cardiol. 2020, 309, 70-77. [CrossRef] [PubMed]

7. Ashraf, U.M.; Abokor, A.A.; Edwards, J.M.; Waigi, E.W.; Royfman, R.S.; Hasan, S.A.; Smedlund, K.B.; Hardy, A.M.G.; Chakravarti, R.; Koch, L.G. SARS-CoV-2, ACE2 expression, and systemic organ invasion. Physiol. Genom. 2020. [CrossRef]

8. Aleksova, A.; Ferro, F.; Gagno, G.; Cappelletto, C.; Santon, D.; Rossi, M.; Ippolito, G.; Zumla, A.; Beltrami, A.P.; Sinagra, G. COVID-19 and renin-angiotensin system inhibition: Role of angiotensin converting enzyme 2 (ACE2)-Is there any scientific evidence for controversy? J. Intern. Med. 2020, 288, 410-421. [CrossRef]

9. Bian, J.; Li, Z. Angiotensin-converting enzyme 2 (ACE2): SARS-CoV-2 receptor and RAS modulator. Acta Pharm. Sin. B 2020. [CrossRef]

10. Clerkin, K.J.; Fried, J.A.; Raikhelkar, J.; Sayer, G.; Griffin, J.M.; Masoumi, A.; Jain, S.S.; Burkhoff, D.; Kumaraiah, D.; Rabbani, L.; et al. COVID-19 and Cardiovascular Disease. Circulation 2020, 141, 1648-1655. [CrossRef] [PubMed]

11. Paces, J.; Strizova, Z.; Smrz, D.; Cerny, J. COVID-19 and the immune system. Physiol. Res. 2020, 69, 379-388. [CrossRef] [PubMed]

12. Sriram, K.; Insel, P.A. A hypothesis for pathobiology and treatment of COVID-19: The centrality of ACE1/ACE2 imbalance. Br. J. Pharmacol. 2020, 177, 4825-4844. [CrossRef] [PubMed]

13. Wang, K.; Gheblawi, M.; Oudit, G.Y. Angiotensin Converting Enzyme 2: A Double-Edged Sword. Circulation 2020, 142, 426-428. [CrossRef] 
14. Zipeto, D.; Palmeira, J.D.F.; Arganaraz, G.A.; Arganaraz, E.R. ACE2/ADAM17/TMPRSS2 Interplay May Be the Main Risk Factor for COVID-19. Front. Immunol. 2020, 11, 576745. [CrossRef] [PubMed]

15. Ragia, G.; Manolopoulos, V.G. Assessing COVID-19 susceptibility through analysis of the genetic and epigenetic diversity of ACE2-mediated SARS-CoV-2 entry. Pharmacogenomics 2020, 21, 1311-1329. [CrossRef] [PubMed]

16. Gheblawi, M.; Wang, K.; Viveiros, A.; Nguyen, Q.; Zhong, J.C.; Turner, A.J.; Raizada, M.K.; Grant, M.B.; Oudit, G.Y. AngiotensinConverting Enzyme 2: SARS-CoV-2 Receptor and Regulator of the Renin-Angiotensin System: Celebrating the 20th Anniversary of the Discovery of ACE2. Circ. Res. 2020, 126, 1456-1474. [CrossRef] [PubMed]

17. Wiese, O.; Zemlin, A.E.; Pillay, T.S. Molecules in pathogenesis: Angiotensin converting enzyme 2 (ACE2). J. Clin. Pathol. 2020. [CrossRef] [PubMed]

18. Oudit, G.Y.; Pfeffer, M.A. Plasma angiotensin-converting enzyme 2: Novel biomarker in heart failure with implications for COVID-19. Eur. Heart J. 2020, 41, 1818-1820. [CrossRef]

19. Cheng, H.; Wang, Y.; Wang, G.Q. Organ-protective effect of angiotensin-converting enzyme 2 and its effect on the prognosis of COVID-19. J. Med. Virol. 2020, 92, 726-730. [CrossRef] [PubMed]

20. Gooz, M. ADAM-17: The enzyme that does it all. Crit. Rev. Biochem. Mol. Biol. 2010, 45, 146-169. [CrossRef]

21. Thunders, M.; Delahunt, B. Gene of the month: TMPRSS2 (transmembrane serine protease 2). J. Clin. Pathol. 2020, 73, 773-776. [CrossRef]

22. Robinson, E.L.; Alkass, K.; Bergmann, O.; Maguire, J.J.; Roderick, H.L.; Davenport, A.P. Genes encoding ACE2, TMPRSS2 and related proteins mediating SARS-CoV-2 viral entry are upregulated with age in human cardiomyocytes. J. Mol. Cell Cardiol. 2020, 147, 88-91. [CrossRef]

23. Bartolome, A.; Liang, J.; Wang, P.; Ho, D.D.; Pajvani, U.B. Angiotensin converting enzyme 2 is a novel target of the gammasecretase complex. bioRxiv 2020. [CrossRef]

24. Lambert, D.W.; Yarski, M.; Warner, F.J.; Thornhill, P.; Parkin, E.T.; Smith, A.I.; Hooper, N.M.; Turner, A.J. Tumor necrosis factoralpha convertase (ADAM17) mediates regulated ectodomain shedding of the severe-acute respiratory syndrome-coronavirus (SARS-CoV) receptor, angiotensin-converting enzyme-2 (ACE2). J. Biol. Chem. 2005, 280, 30113-30119. [CrossRef]

25. Heurich, A.; Hofmann-Winkler, H.; Gierer, S.; Liepold, T.; Jahn, O.; Pohlmann, S. TMPRSS2 and ADAM17 cleave ACE2 differentially and only proteolysis by TMPRSS2 augments entry driven by the severe acute respiratory syndrome coronavirus spike protein. J. Virol. 2014, 88, 1293-1307. [CrossRef]

26. Schutz, D.; Ruiz-Blanco, Y.B.; Munch, J.; Kirchhoff, F.; Sanchez-Garcia, E.; Muller, J.A. Peptide and peptide-based inhibitors of SARS-CoV-2 entry. Adv. Drug Deliv. Rev. 2020, 167, 47-65. [CrossRef] [PubMed]

27. Chen, Y.; Liu, Q.; Guo, D. Emerging coronaviruses: Genome structure, replication, and pathogenesis. J. Med. Virol. 2020, 92, 418-423. [CrossRef]

28. Walls, A.C.; Tortorici, M.A.; Snijder, J.; Xiong, X.; Bosch, B.J.; Rey, F.A.; Veesler, D. Tectonic conformational changes of a coronavirus spike glycoprotein promote membrane fusion. Proc. Natl. Acad. Sci. USA 2017, 114, 11157-11162. [CrossRef] [PubMed]

29. Ragab, D.; Salah Eldin, H.; Taeimah, M.; Khattab, R.; Salem, R. The COVID-19 Cytokine Storm; What We Know So Far. Front. Immunol. 2020, 11, 1446. [CrossRef] [PubMed]

30. van der Vorst, E.P.C.; Weber, C.; Donners, M. A Disintegrin and Metalloproteases (ADAMs) in Cardiovascular, Metabolic and Inflammatory Diseases: Aspects for Theranostic Approaches. Thromb. Haemost. 2018, 118, 1167-1175. [CrossRef] [PubMed]

31. Casanova, J.L.; Su, H.C.; Effort, C.H.G. A Global Effort to Define the Human Genetics of Protective Immunity to SARS-CoV-2 Infection. Cell 2020, 181, 1194-1199. [CrossRef]

32. Cao, Y.; Li, L.; Feng, Z.; Wan, S.; Huang, P.; Sun, X.; Wen, F.; Huang, X.; Ning, G.; Wang, W. Comparative genetic analysis of the novel coronavirus (2019-nCoV/SARS-CoV-2) receptor ACE2 in different populations. Cell Discov. 2020, 6, 11. [CrossRef]

33. Brest, P.; Refae, S.; Mograbi, B.; Hofman, P.; Milano, G. Host Polymorphisms May Impact SARS-CoV-2 Infectivity. Trends Genet. 2020, 36, 813-815. [CrossRef]

34. Singh, H.; Choudhari, R.; Nema, V.; Khan, A.A. ACE2 and TMPRSS2 polymorphisms in various diseases with special reference to its impact on COVID-19 disease. Microb. Pathog. 2020, 150, 104621. [CrossRef]

35. Choudhary, S.; Sreenivasulu, K.; Mitra, P.; Misra, S.; Sharma, P. Role of Genetic Variants and Gene Expression in the Susceptibility and Severity of COVID-19. Ann. Lab. Med. 2021, 41, 129-138. [CrossRef]

36. Devaux, C.A.; Rolain, J.M.; Raoult, D. ACE2 receptor polymorphism: Susceptibility to SARS-CoV-2, hypertension, multi-organ failure, and COVID-19 disease outcome. J. Microbiol. Immunol. Infect. 2020, 53, 425-435. [CrossRef]

37. Gasmi, A.; Peana, M.; Pivina, L.; Srinath, S.; Benahmed, A.G.; Semenova, Y.; Menzel, A.; Dadar, M.; Bjorklund, G. Interrelations between COVID-19 and other disorders. Clin. Immunol. 2020, 108651. [CrossRef]

38. Oakes, J.M.; Fuchs, R.M.; Gardner, J.D.; Lazartigues, E.; Yue, X. Nicotine and the renin-angiotensin system. Am. J. Physiol. Regul. Integr. Comp. Physiol. 2018, 315, R895-R906. [CrossRef] [PubMed]

39. Russo, P.; Bonassi, S.; Giacconi, R.; Malavolta, M.; Tomino, C.; Maggi, F. COVID-19 and smoking: Is nicotine the hidden link? Eur. Respir. J. 2020, 55. [CrossRef] [PubMed]

40. Jimenez-Ruiz, C.A.; Lopez-Padilla, D.; Alonso-Arroyo, A.; Aleixandre-Benavent, R.; Solano-Reina, S.; de Granda-Orive, J.I. COVID-19 and Smoking: A Systematic Review and Meta-Analysis of the Evidence. Arch. Bronconeumol. 2020. [CrossRef]

41. Vardavas, C.I.; Nikitara, K. COVID-19 and smoking: A systematic review of the evidence. Tob. Induc. Dis. 2020, 18, 20. [CrossRef] 
42. Smith, J.C.; Sausville, E.L.; Girish, V.; Yuan, M.L.; Vasudevan, A.; John, K.M.; Sheltzer, J.M. Cigarette Smoke Exposure and Inflammatory Signaling Increase the Expression of the SARS-CoV-2 Receptor ACE2 in the Respiratory Tract. Dev. Cell 2020, 53, 514-529.e3. [CrossRef] [PubMed]

43. Chen, J.; Jiang, Q.; Xia, X.; Liu, K.; Yu, Z.; Tao, W.; Gong, W.; Han, J.J. Individual variation of the SARS-CoV-2 receptor ACE2 gene expression and regulation. Aging Cell 2020, 19. [CrossRef] [PubMed]

44. Fernandez-Atucha, A.; Izagirre, A.; Fraile-Bermudez, A.B.; Kortajarena, M.; Larrinaga, G.; Martinez-Lage, P.; Echevarria, E.; Gil, J. Sex differences in the aging pattern of renin-angiotensin system serum peptidases. Biol. Sex Differ. 2017, 8, 5. [CrossRef] [PubMed]

45. Viveiros, A.; Rasmuson, J.; Vu, J.; Mulvagh, S.L.; Yip, C.Y.Y.; Norris, C.M.; Oudit, G.Y. Sex Differences in COVID-19: Candidate Pathways, Genetics of ACE2, and Sex Hormones. Am. J. Physiol. Heart Circ. Physiol. 2020. [CrossRef]

46. Gupte, M.; Thatcher, S.E.; Boustany-Kari, C.M.; Shoemaker, R.; Yiannikouris, F.; Zhang, X.; Karounos, M.; Cassis, L.A. Angiotensin converting enzyme 2 contributes to sex differences in the development of obesity hypertension in C57BL/6 mice. Arter. Thromb. Vasc. Biol. 2012, 32, 1392-1399. [CrossRef] [PubMed]

47. La Vignera, S.; Cannarella, R.; Condorelli, R.A.; Torre, F.; Aversa, A.; Calogero, A.E. Sex-Specific SARS-CoV-2 Mortality: Among Hormone-Modulated ACE2 Expression, Risk of Venous Thromboembolism and Hypovitaminosis D. Int. J. Mol. Sci. 2020, 21, 2948. [CrossRef]

48. Sward, P.; Edsfeldt, A.; Reepalu, A.; Jehpsson, L.; Rosengren, B.E.; Karlsson, M.K. Age and sex differences in soluble ACE2 may give insights for COVID-19. Crit. Care 2020, 24, 221. [CrossRef]

49. Li, Y.; Xu, Q.; Ma, L.; Wu, D.; Gao, J.; Chen, G.; Li, H. Systematic profiling of ACE2 expression in diverse physiological and pathological conditions for COVID-19/SARS-CoV-2. J. Cell. Mol. Med. 2020, 24, 9478-9482. [CrossRef] [PubMed]

50. Patel, S.K.; Velkoska, E.; Freeman, M.; Wai, B.; Lancefield, T.F.; Burrell, L.M. From gene to protein-experimental and clinical studies of ACE2 in blood pressure control and arterial hypertension. Front. Physiol 2014, 5, 227. [CrossRef]

51. Sama, I.E.; Voors, A.A. Circulating plasma angiotensin-converting enzyme 2 concentration is elevated in patients with kidney disease and diabetes. Eur. Heart J. 2020, 41, 3099. [CrossRef]

52. Epelman, S.; Tang, W.H.; Chen, S.Y.; Van Lente, F.; Francis, G.S.; Sen, S. Detection of soluble angiotensin-converting enzyme 2 in heart failure: Insights into the endogenous counter-regulatory pathway of the renin-angiotensin-aldosterone system. J. Am. Coll. Cardiol. 2008, 52, 750-754. [CrossRef] [PubMed]

53. Raedle-Hurst, T.; Wissing, S.; Mackenstein, N.; Obeid, R.; Geisel, J.; Wagenpfeil, S.; Abdul-Khaliq, H. Determinants of soluble angiotensin-converting enzyme 2 concentrations in adult patients with complex congenital heart disease. Clin. Res. Cardiol. 2020. [CrossRef]

54. Crowley, S.D.; Gurley, S.B.; Herrera, M.J.; Ruiz, P.; Griffiths, R.; Kumar, A.P.; Kim, H.-S.; Smithies, O.; Le, T.H.; Coffman, T.M. Angiotensin II causes hypertension and cardiac hypertrophy through its receptors in the kidney. Proc. Natl. Acad. Sci. USA 2006, 103, 17985-17990. [CrossRef]

55. Ruan, Q.; Yang, K.; Wang, W.; Jiang, L.; Song, J. Clinical predictors of mortality due to COVID-19 based on an analysis of data of 150 patients from Wuhan, China. Intensive Care Med. 2020, 46, 846-848. [CrossRef] [PubMed]

56. Wicik, Z.; Eyileten, C.; Jakubik, D.; Simoes, S.N.; Martins, D.C., Jr.; Pavao, R.; Siller-Matula, J.M.; Postula, M. ACE2 Interaction Networks in COVID-19: A Physiological Framework for Prediction of Outcome in Patients with Cardiovascular Risk Factors. J. Clin. Med. 2020, 9, 3743. [CrossRef] [PubMed]

57. Mishra, A.; Chanchal, S.; Ashraf, M.Z. Host-Viral Interactions Revealed among Shared Transcriptomics Signatures of ARDS and Thrombosis: A Clue into COVID-19 Pathogenesis. TH Open 2020, 4, e403-e412. [CrossRef]

58. Kuba, K.; Imai, Y.; Rao, S.; Jiang, C.; Penninger, J.M. Lessons from SARS: Control of acute lung failure by the SARS receptor ACE2. J. Mol. Med. 2006, 84, 814-820. [CrossRef] [PubMed]

59. Zhao, Y.; Zhao, Z.; Wang, Y.; Zhou, Y.; Ma, Y.; Zuo, W. Single-Cell RNA Expression Profiling of ACE2, the Receptor of SARS-CoV-2. Am. J. Respir. Crit. Care Med. 2020, 202, 756-759. [CrossRef]

60. Zhang, H.; Penninger, J.M.; Li, Y.; Zhong, N.; Slutsky, A.S. Angiotensin-converting enzyme 2 (ACE2) as a SARS-CoV-2 receptor: Molecular mechanisms and potential therapeutic target. Intensive Care Med. 2020, 46, 586-590. [CrossRef]

61. Liu, M.Y.; Zheng, B.; Zhang, Y.; Li, J.P. Role and mechanism of angiotensin-converting enzyme 2 in acute lung injury in coronavirus disease 2019. Chronic Dis. Transl. Med. 2020, 6, 98-105. [CrossRef]

62. Vivek-Ananth, R.P.; Rana, A.; Rajan, N.; Biswal, H.S.; Samal, A. In Silico Identification of Potential Natural Product Inhibitors of Human Proteases Key to SARS-CoV-2 Infection. Molecules 2020, 25, 3822. [CrossRef]

63. Falasca, L.; Nardacci, R.; Colombo, D.; Lalle, E.; Di Caro, A.; Nicastri, E.; Antinori, A.; Petrosillo, N.; Marchioni, L.; Biava, G.; et al. Postmortem Findings in Italian Patients with COVID-19: A Descriptive Full Autopsy Study of Cases with and without Comorbidities. J. Infect. Dis. 2020, 222, 1807-1815. [CrossRef]

64. Bojkova, D.; Wagner, J.U.G.; Shumliakivska, M.; Aslan, G.S.; Saleem, U.; Hansen, A.; Luxan, G.; Gunther, S.; Pham, M.D.; Krishnan, J.; et al. SARS-CoV-2 infects and induces cytotoxic effects in human cardiomyocytes. Cardiovasc. Res. 2020, 116, 2207-2215. [CrossRef] [PubMed]

65. Teuwen, L.A.; Geldhof, V.; Pasut, A.; Carmeliet, P. COVID-19: The vasculature unleashed. Nat. Rev. Immunol. 2020, 20, 389-391. [CrossRef] [PubMed]

66. Maiese, A.; Manetti, A.C.; La Russa, R.; Di Paolo, M.; Turillazzi, E.; Frati, P.; Fineschi, V. Autopsy findings in COVID-19-related deaths: A literature review. Forensic Sci. Med. Pathol. 2020. [CrossRef] [PubMed] 
67. Basso, C.; Leone, O.; Rizzo, S.; De Gaspari, M.; van der Wal, A.C.; Aubry, M.C.; Bois, M.C.; Lin, P.T.; Maleszewski, J.J.; Stone, J.R. Pathological features of COVID-19-associated myocardial injury: A multicentre cardiovascular pathology study. Eur. Heart J. 2020, 41, 3827-3835. [CrossRef]

68. Ackermann, M.; Verleden, S.E.; Kuehnel, M.; Haverich, A.; Welte, T.; Laenger, F.; Vanstapel, A.; Werlein, C.; Stark, H.; Tzankov, A.; et al. Pulmonary Vascular Endothelialitis, Thrombosis, and Angiogenesis in Covid-19. N. Engl. J. Med. 2020, 383, 120-128. [CrossRef] [PubMed]

69. Dhakal, B.P.; Sweitzer, N.K.; Indik, J.H.; Acharya, D.; William, P. SARS-CoV-2 Infection and Cardiovascular Disease: COVID-19 Heart. Heart Lung Circ. 2020, 29, 973-987. [CrossRef]

70. Ibanez, B.; James, S.; Agewall, S.; Antunes, M.J.; Bucciarelli-Ducci, C.; Bueno, H.; Caforio, A.L.P.; Crea, F.; Goudevenos, J.A.; Halvorsen, S.; et al. 2017 ESC Guidelines for the management of acute myocardial infarction in patients presenting with ST-segment elevation. Rev. Esp. Cardiol. 2017, 70, 1082. [CrossRef]

71. Ponikowski, P.; Voors, A.A.; Anker, S.D.; Bueno, H.; Cleland, J.G.F.; Coats, A.J.S.; Falk, V.; Gonzalez-Juanatey, J.R.; Harjola, V.P.; Jankowska, E.A.; et al. 2016 ESC Guidelines for the Diagnosis and Treatment of Acute and Chronic Heart Failure. Rev. Esp. Cardiol. 2016, 69, 1167. [CrossRef] [PubMed]

72. Giavina-Bianchi, P.; Aun, M.V.; Agondi, R.C.; Kalil, J. Debate on drugs that may aggravate COVID-19. J. Allergy Clin. Immunol. Pract. 2020, 8, 2452-2453. [CrossRef]

73. Savarese, G.; Benson, L.; Sundstrom, J.; Lund, L.H. Association between renin-angiotensin-aldosterone system inhibitor use and COVID-19 hospitalization and death: A 1.4 million patient nationwide registry analysis. Eur. J. Heart Fail. 2020. [CrossRef] [PubMed]

74. Zhang, P.; Zhu, L.; Cai, J.; Lei, F.; Qin, J.J.; Xie, J.; Liu, Y.M.; Zhao, Y.C.; Huang, X.; Lin, L.; et al. Association of Inpatient Use of Angiotensin-Converting Enzyme Inhibitors and Angiotensin II Receptor Blockers with Mortality Among Patients with Hypertension Hospitalized with COVID-19. Circ. Res. 2020, 126, 1671-1681. [CrossRef] [PubMed]

75. Trifiro, G.; Massari, M.; Da Cas, R.; Menniti Ippolito, F.; Sultana, J.; Crisafulli, S.; Giorgi Rossi, P.; Marino, M.; Zorzi, M.; Bovo, E.; et al. Renin-Angiotensin-Aldosterone System Inhibitors and Risk of Death in Patients Hospitalised with COVID-19: A Retrospective Italian Cohort Study of 43,000 Patients. Drug Saf. 2020, 43, 1297-1308. [CrossRef]

76. Mancia, G.; Rea, F.; Ludergnani, M.; Apolone, G.; Corrao, G. Renin-Angiotensin-Aldosterone System Blockers and the Risk of Covid-19. N. Engl. J. Med. 2020, 382, 2431-2440. [CrossRef]

77. Rossi, L.; Malagoli, A.; Biagi, A.; Zanni, A.; Sticozzi, C.; Comastri, G.; Pannone, L.; Gandolfi, S.; Vergara, P.; Villani, G.Q. Renin-angiotensin system inhibitors and mortality in patients with COVID-19. Infection 2020. [CrossRef]

78. Ssentongo, A.E.; Ssentongo, P.; Heilbrunn, E.S.; Lekoubou, A.; Du, P.; Liao, D.; Oh, J.S.; Chinchilli, V.M. Renin-angiotensinaldosterone system inhibitors and the risk of mortality in patients with hypertension hospitalised for COVID-19: Systematic review and meta-analysis. Open Heart 2020, 7. [CrossRef] [PubMed]

79. Zhang, G.; Wu, Y.; Xu, R.; Du, X. Effects of renin-angiotensin-aldosterone system inhibitors on disease severity and mortality in patients with COVID-19: A meta-analysis. J. Med. Virol. 2020. [CrossRef]

80. Lopes, R.D.; Macedo, A.V.S.; de Barros, E.S.P.G.M.; Moll-Bernardes, R.J.; Feldman, A.; D'Andrea Saba Arruda, G.; de Souza, A.S.; de Albuquerque, D.C.; Mazza, L.; Santos, M.F.; et al. Continuing versus suspending angiotensin-converting enzyme inhibitors and angiotensin receptor blockers: Impact on adverse outcomes in hospitalized patients with severe acute respiratory syndrome coronavirus 2 (SARS-CoV-2)—The BRACE CORONA Trial. Am. Heart J. 2020, 226, 49-59. [CrossRef]

81. Lim, J.H.; Cho, J.H.; Jeon, Y.; Kim, J.H.; Lee, G.Y.; Jeon, S.; Noh, H.W.; Lee, Y.H.; Lee, J.; Chang, H.H.; et al. Adverse impact of renin-angiotensin system blockade on the clinical course in hospitalized patients with severe COVID-19: A retrospective cohort study. Sci. Rep. 2020, 10, 20250. [CrossRef]

82. Liabeuf, S.; Moragny, J.; Bennis, Y.; Batteux, B.; Brochot, E.; Schmit, J.L.; Lanoix, J.P.; Andrejak, C.; Ganry, O.; Slama, M.; et al. Association between renin-angiotensin system inhibitors and COVID-19 complications. Eur. Heart J. Cardiovasc. Pharm. 2020. [CrossRef]

83. WHO Draft Landscape of COVID-19 Candidate Vaccines. Available online: https://www.who.int/publications/m/item/draftlandscape-of-covid-19-candidate-vaccines (accessed on 11 February 2021).

84. EMA Coronavirus Disease (COVID-19). Available online: https://www.ema.europa.eu/en/human-regulatory/overview/ public-health-threats / coronavirus-disease-covid-19 (accessed on 11 February 2021).

85. FDA COVID-19 Vaccines. Available online: https://www.fda.gov/emergency-preparedness-and-response/coronavirus-disease2019-covid-19/covid-19-vaccines (accessed on 11 February 2021).

86. Dong, Y.; Dai, T.; Wei, Y.; Zhang, L.; Zheng, M.; Zhou, F. A systematic review of SARS-CoV-2 vaccine candidates. Signal Transduct. Target. Ther. 2020, 5, 237. [CrossRef] [PubMed]

87. Krammer, F. SARS-CoV-2 vaccines in development. Nature 2020, 586, 516-527. [CrossRef] [PubMed]

88. EMA COVID-19 Vaccines: Under Evaluation. Available online: https://www.ema.europa.eu/en/human-regulatory/ overview / public-health-threats / coronavirus-disease-covid-19/treatments-vaccines/vaccines-covid-19/covid-19-vaccinesunder-evaluation\#covid-19-vaccines-under-conditional-marketing-authorisation-evaluation-section (accessed on 7 April 2021).

89. Nanomedicine and the COVID-19 vaccines. Nat. Nanotechnol. 2020, 15, 963. [CrossRef]

90. Baden, L.R.; El Sahly, H.M.; Essink, B.; Kotloff, K.; Frey, S.; Novak, R.; Diemert, D.; Spector, S.A.; Rouphael, N.; Creech, C.B.; et al. Efficacy and Safety of the mRNA-1273 SARS-CoV-2 Vaccine. N. Engl. J. Med. 2020. [CrossRef] 
91. Polack, F.P.; Thomas, S.J.; Kitchin, N.; Absalon, J.; Gurtman, A.; Lockhart, S.; Perez, J.L.; Perez Marc, G.; Moreira, E.D.; Zerbini, C.; et al. Safety and Efficacy of the BNT162b2 mRNA Covid-19 Vaccine. N. Engl. J. Med. 2020, 383, 2603-2615. [CrossRef] [PubMed]

92. Voysey, M.; Clemens, S.A.C.; Madhi, S.A.; Weckx, L.Y.; Folegatti, P.M.; Aley, P.K.; Angus, B.; Baillie, V.L.; Barnabas, S.L.; Bhorat, Q.E.; et al. Safety and efficacy of the ChAdOx1 nCoV-19 vaccine (AZD1222) against SARS-CoV-2: An interim analysis of four randomised controlled trials in Brazil, South Africa, and the UK. Lancet 2021, 397, 99-111. [CrossRef]

93. Østergaard, S.D.; Schmidt, M.; Horváth-Puhó, E.; Thomsen, R.W.; Sørensen, H.T. Thromboembolism and the Oxford-AstraZeneca COVID-19 vaccine: Side-effect or coincidence? Lancet 2021, 397, 1441-1443. [CrossRef]

94. ReiThera Covid-19: Our Efforts against Coronavirus. Available online: https:/ /www.reithera.com/ (accessed on 26 April 2021).

95. AIFA COVID-19-AIFA Autorizza la Sperimentazione di Fase I del Vaccino ReiThera in Italia. Available online: https://www. aifa.gov.it/en/- / covid-19-alfa-autorizza-la-sperimentazione-di-fase-i-del-vaccino-reithera-in-italia (accessed on 11 February 2021).

96. Study of GRAd-COV2 for the Prevention of COVID-19 in Adults (COVITAR). Available online: https: / clinicaltrials.gov / ct2 / show / NCT04791423 (accessed on 26 April 2021).

97. Rock, K.L.; Reits, E.; Neefjes, J. Present Yourself! By MHC Class I and MHC Class II Molecules. Trends Immunol. 2016, 37, 724-737. [CrossRef]

98. Barrett, J.R.; Belij-Rammerstorfer, S.; Dold, C.; Ewer, K.J.; Folegatti, P.M.; Gilbride, C.; Halkerston, R.; Hill, J.; Jenkin, D.; Stockdale, L.; et al. Phase $1 / 2$ trial of SARS-CoV-2 vaccine ChAdOx1 nCoV-19 with a booster dose induces multifunctional antibody responses. Nat. Med. 2020. [CrossRef]

99. Kuba, K.; Imai, Y.; Rao, S.; Gao, H.; Guo, F.; Guan, B.; Huan, Y.; Yang, P.; Zhang, Y.; Deng, W.; et al. A crucial role of angiotensin converting enzyme 2 (ACE2) in SARS coronavirus-induced lung injury. Nat. Med. 2005, 11, 875-879. [CrossRef]

100. Lei, Y.; Zhang, J.; Schiavon, C.R.; He, M.; Chen, L.; Shen, H.; Zhang, Y.; Yin, Q.; Cho, Y.; Andrade, L.; et al. SARS-CoV-2 Spike Protein Impairs Endothelial Function via Downregulation of ACE2. bioRxiv 2020. [CrossRef]

101. The Lancet Diabetes \& Endocrinology. Coronavirus vaccine? Join the queue. Lancet Diabetes Endocrinol. 2021, 9, 1. [CrossRef]

102. Tumban, E. Lead SARS-CoV-2 Candidate Vaccines: Expectations from Phase III Trials and Recommendations Post-Vaccine Approval. Viruses 2020, 13, 54. [CrossRef] [PubMed]

103. Darby, A.C.; Hiscox, J.A. Covid-19: Variants and vaccination. BMJ 2021, 372, n771. [CrossRef] [PubMed]

104. Focosi, D.; Tuccori, M.; Franchini, M. The Road towards Polyclonal Anti-SARS-CoV-2 Immunoglobulins (Hyperimmune Serum) for Passive Immunization in COVID-19. Life 2021, 11, 144. [CrossRef] [PubMed]

105. Chen, H.; Zhang, X.; Liu, W.; Xue, M.; Liao, C.; Huang, Z.; Hu, H.; Sun, B. The role of serum specific- SARS-CoV-2 antibody in COVID-19 patients. Int. Immunopharmacol. 2021, 91, 107325. [CrossRef]

106. Wang, P.; Nair, M.S.; Liu, L.; Iketani, S.; Luo, Y.; Guo, Y.; Wang, M.; Yu, J.; Zhang, B.; Kwong, P.D.; et al. Antibody resistance of SARS-CoV-2 variants B.1.351 and B.1.1.7. Nature 2021. [CrossRef]

107. Moyo-Gwete, T.; Madzivhandila, M.; Makhado, Z.; Ayres, F.; Mhlanga, D.; Oosthuysen, B.; Lambson, B.E.; Kgagudi, P.; Tegally, H.; Iranzadeh, A.; et al. SARS-CoV-2 501Y.V2 (B.1.351) elicits cross-reactive neutralizing antibodies. bioRxiv 2021. [CrossRef]

108. Ferasin, L.; Fritz, M.; Ferasin, H.; Becquart, P.; Legros, V.; Leroy, E.M. Myocarditis in naturally infected pets with the British variant of COVID-19. bioRxiv 2021, 435945. [CrossRef]

109. Anderson, E.J.; Rouphael, N.G.; Widge, A.T.; Jackson, L.A.; Roberts, P.C.; Makhene, M.; Chappell, J.D.; Denison, M.R.; Stevens, L.J.; Pruijssers, A.J.; et al. Safety and Immunogenicity of SARS-CoV-2 mRNA-1273 Vaccine in Older Adults. N. Engl. J. Med. 2020, 383, 2427-2438. [CrossRef]

110. Ramasamy, M.N.; Minassian, A.M.; Ewer, K.J.; Flaxman, A.L.; Folegatti, P.M.; Owens, D.R.; Voysey, M.; Aley, P.K.; Angus, B.; Babbage, G.; et al. Safety and immunogenicity of ChAdOx1 nCoV-19 vaccine administered in a prime-boost regimen in young and old adults (COV002): A single-blind, randomised, controlled, phase 2/3 trial. Lancet 2021, 396, 1979-1993. [CrossRef] 